\title{
Government Initiatives for Green Development in Bangladesh
}

\author{
Md. Anowar Hossain Bhuiyan ${ }^{1 *}$, Shafiqul Hassan ${ }^{2 *}$, Md. Abud Darda ${ }^{3}$, Md. Wahidul Habib ${ }^{4}$, Md. \\ Belal Hossain 5 \\ ${ }^{1}$ Assistant Professor (Management), National University, Gazipur-1704, Bangladesh \\ (anowarlestari@gmail.com) \\ ${ }^{2}$ Assistant Professor, Prince Sultan University, Riyadh 11586, Kingdom of Saudi Arabia \\ (shassan@psu.edu.sa) \\ ${ }^{3}$ Associate Professor (Statistics), National University, Gazipur-1704, Bangladesh (dardabd@ gmail.com) \\ ${ }^{4}$ Assistant Professor, Faculty of Business, ASA University Bangladesh, Dhaka, Bangladesh \\ (wahidu1123@yahoo.co.uk) \\ ${ }^{5}$ School of Economics and Management, China Three Gorges University, Yichang, Hubei, People's \\ Republic of China (belal@ctgu.edu.cn) \\ "Corresponding Authors
}

\begin{abstract}
:
Green development ensures the socioeconomic development that incorporates environmental issues while remaining economically viable for owners and tenants. Government as the authority of the state should provide favorable incentives, policy and regulatory pressure for green development. The present study aims to investigate the government policies and regulations for green development in Bangladesh and make a critical discussion of the initiatives. The study is descriptive in nature and collects secondary information. Evidence suggests that environmental degradation and climate change related risks and vulnerabilities have intensified in Bangladesh. The government of Bangladesh (GOB) is concerned about green development and formulates various Acts, regulations and policy initiatives since 2010. Major green development initiatives observed in the financial institutions due to the mandatory requirements by Bangladesh Bank but green bond and green insurance in capital market are yet to be developed. The GOB required taking proper policy initiatives for the garments and leather industries to ensure pollution free production system which ensures green trade initiatives. The environmental taxes and ecological compensation mechanisms should be revised. Urban green space and Government green procurement are still less concerning matter. The GOB should make effective collaboration with all related stakeholders to ensure the green development.
\end{abstract}

Keywords: Bangladesh; Government; Green development

\section{Introduction:}

Green development is a holistic approach of ensuring economic and social development considering the environmental impacts. It promotes the mechanisms for energy saving, pollution reduction, recycling the waste, innovate green products, efficient use of resources, and environmental management (Huang, et al. 2019). Government, as the authority of the state provides favourable incentives (Paramati et al. 2016) and regulatory pressures (Berrone et al. 
2013) for green development. Hafezalkotob et al. (2016) emphasized on policies to encourage green production and effective supply chains for green development. The government green policy initiatives reduce negative impacts and ensure societal harmony due to development (Anand and Gaur 2019). These initiatives also create positive emotions and supportive responses among the public towards government (Gaur and Kumar 2018). Moreover, government spends and support the green initiatives to protect the environment (Chen and Chai 2010). Mohanty (2012) addressed green development as carbon emission reduction mechanism to achieve sustainable development through green growth.

The government subsidies and taxation rebate initiatives create positive influence on total investment efficiency. These initiatives also show significant impacts on firms and ownership levels. The government policy instruments can attract attention in society and academia for environmental conservation activities (Nesshöver et al. 2016). There are some policy initiatives for environmental conservation such as, regulatory instruments, fiscal transfer schemes, economic instruments, and distributing public money (Droste et al. 2017). Fiscal transfer and finance mechanism for biodiversity conservation have been considered as meaningful environmental fiscal policies in the world (OECD 2013). Some EU countries have adopted several policy initiatives to reduce carbon emission for ensuring sustainable development. The important policy initiatives include carbon tax on electricity to reduce emission from power plants, energy efficiency through reduction of emission, subsidy to renewable energy, and reduce energy demands (Srivastava and Kumar 2014).

Government green initiatives promote the projects to provide funding in low carbon economy (Toyin and Toyin 2019). Green initiatives can reduce the extraction of carbon emission and pollution in the country (Franks et al. 2015). Moreover, green initiatives explore opportunities for green finance in sustainable innovation and green investment (Falcone and Sica 2019). Pigato et al. (2018) revealed that government green initiatives support the green finance to mitigate climate change related negative impacts and generate funding for green investment in developing countries. The major challenges for implementation of green projects are- lack of legal and regulatory framework, accessible financing, and supports of financial institutions. Financial institutions appear that investment risks are involved in green projects rather than conventional projects (Yoshino and Taghizadeh-Hesary 2018). Verma and Gayithri (2018) pointed that government environmental fiscal instrument classified by subsidies and taxes. The subsidies are environmental subsidy and environmental tax expenditure. On the other hand, environmental taxes or charges are energy taxes, transport taxes, resources taxes, and pollution taxes.

Bangladesh is one of the vulnerable countries in the world due to climate change related negative impacts. The natural disasters like cyclone, excessive rain, floods, droughts, river erosion are hampering the life of people and economy almost every year. In this case, green fiscal initiatives are essential for the country in order to mitigate the climate change impacts and reduce the negative impacts of natural disasters for ensuring sustainable livelihood of people as well as sustainable development (Voumik and Shah 2014). Government of Bangladesh (GOB) already concerned about green development. Various ministries, divisions and regulatory boards including Bangladesh Bank (BB) formulate several acts, regulations and policy initiatives in this aspect. The aim of this study is to investigate the government policies and regulations for green development of Bangladesh and make a critical discussion of the initiatives. 


\section{Conceptual Framework:}

$\mathrm{Hu}$ et al. (2018) addressed that green development requires green restructuring of resource use, green production process, and ensure mutual benefits between nature and human. The main aspects of green development are- optimize ecological space, build climate adaptive, environment-friendly and resource-saving society, and protect natural ecosystem. The mentionable initiatives for green development are green credit, green banking, environmental compensation mechanism, environmental tax, green trade, government green procurement, green insurance and green securities, urban green spaces, and green innovation (Figure 1).

Green credit: It is a regulatory tool initiated to provide credit scheme to green projects on preferential terms. This green financial instrument is potential for the bank, their stakeholders and other financial sector as well as meets the social and environmental challenges of society. The related policies and procedures have been used by banks and financial institutions to promote green credits through the assessment of environmental impact. There are several initiatives/guidelines implemented in China for green credit such as availability of information, develop necessary tools, capacity building and partnerships, clarify the policies, promote incentives, and enable domestic environment (Aizawa and Yang 2010). The green credit has three components- enhance management of environmental performance of commercial banks, sharing environmental information between financial sector and environmental authority, and liabilities for properly following the policy.

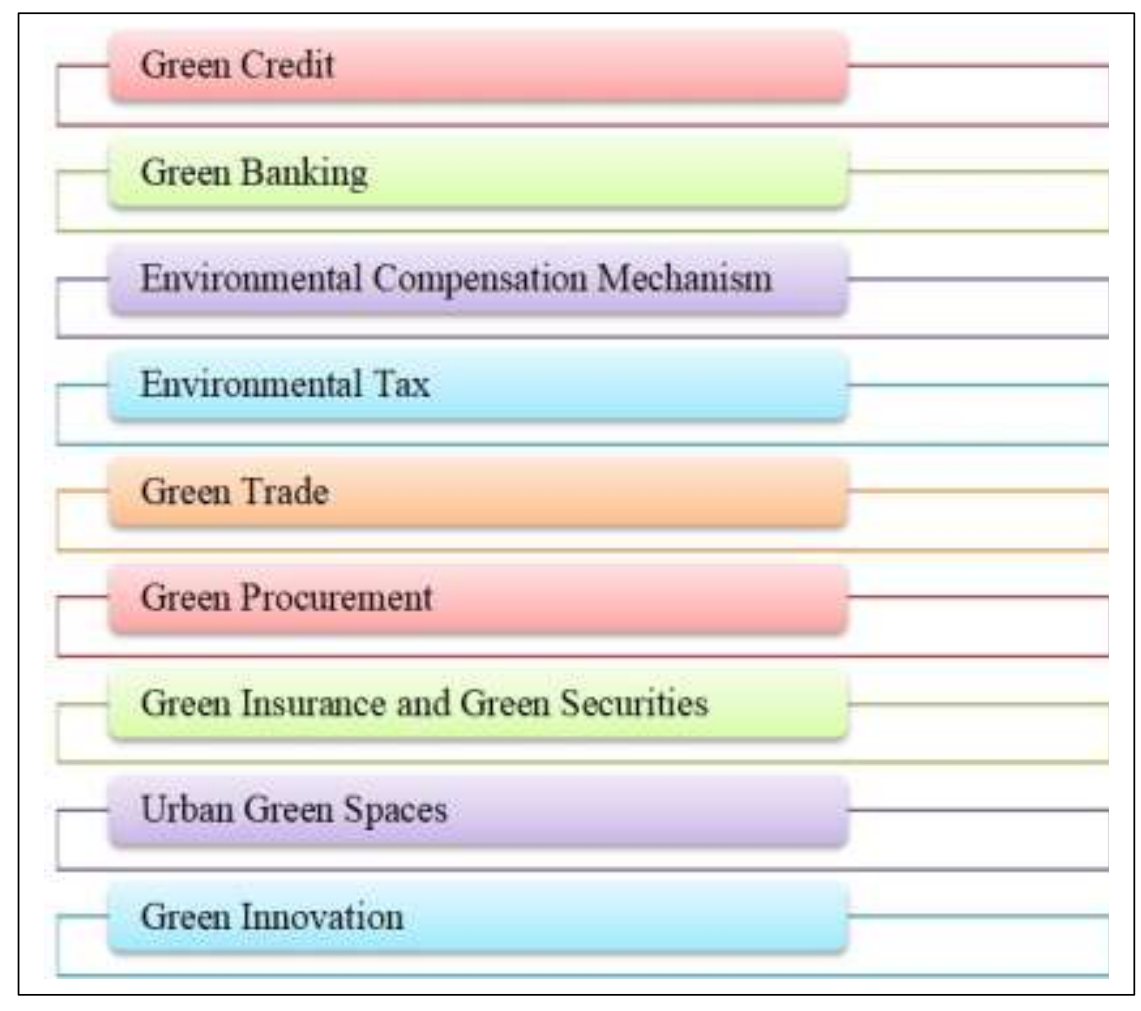

Figure 1: Some mentionable initiatives for green development 
Green Banking: Green banking is a subset of sustainable banking which ensure environmental and social well-beings (Dufays 2012). The aim of this banking is encouraging social and environmental responsibility through ensuring better banking services (Bihari 2011). Green banking is promoting environment friendly technologies and green credit in business sector (Furrer et al. 2012).

Environmental tax: The attempt of environmental tax is to impose duty based on pollution levels for different products and industries. These tax initiatives ensure green development through environment friendly production (Verma and Gayithri 2018).

Ecological compensation mechanism: Ecological compensation mechanism calculates environmental reparation based on water quality and pollution extract due to production. Ecological compensation is imposing to protect the natural resources in an area. Government promotes environment compensation through environmental regulations, ecological investment, ecological innovations which contributes for green development (Acemoglu et al. 2016; Chen and Nie 2016).

Green trade: Green trade emphasize on environmental impact on production, domestic trade and exports. In this case, pollution and environmental risks consider for rebates in export and revise the policies for trade. Gerlach and Zheng (2018) pointed that effective government policies and incentive management can ensure green production and business activities.

Government green procurement: Government gives emphasize to procure the products with environment labels. In this case, government develop the procurement requirements and set up necessary regulations in the policies. Government green procurement consider as climate change intervention in procurement to reduce greenhouse gas (GHG) emissions. This is related to purchase goods and services to consider the negative impacts on the environment due to climate change (Agyepong and Nhamo 2017).

Green insurance: Green insurance system develops guidelines for the enterprises that use, store, produce, transport, and dispose hazardous chemicals for commercial purposes. Wang et al. (2017) addressed that government can encourage the business enterprises for environment friendly innovation through green insurance.

Green securities: This system follows the mandatory requirements on environmental performance for pollution to launch initial public offering (IPO). In this case, the companies take environmental performance approval from the related authorities. The listed companies also have obligation to disclose their environmental performance publicly (CSRC 2008).

Urban green space: Urban green space is a development and infrastructure technique in urban area for affordability, environmental and economic well-beings. Matthews et al. (2015) addressed that green space concept related to green infrastructure through ensure business oriented approaches. Urban green spaces provide environmental benefits through their effects on negating urban heat, offsetting greenhouse gas emissions, and attenuating storm water (Lee et al. 2015). Again, Mell (2017) proposed 'green infrastructure' as landscape approach for design and planning of infrastructure in urban areas. It ensures ecological balance of urban green spaces 
(Tzoulas et al. 2007), and integrated approaches among the related stakeholders (Lennon et al. 2017).

Green innovation: The green innovation management has been emphasized to practitioners and academia for the last several years (Schiederig et al. 2012). Government influences green innovation in a country for better environmental performance (Lewis 2012). Moreover, Kim and Park (2016) addressed that green innovation reduces carbon emissions and leads to financial development.

\section{Methodology:}

The study is descriptive in nature that provides policy analysis. It has developed a theoretical framework for green development in Bangladesh with relevant green initiatives. Secondary sources of information such as policies, regulations and plans of relevant ministries and government agencies of Bangladesh has been consulted and discussed. Moreover, the study reviewed research articles, documents and policy briefs to identify the potential government initiatives for green development in Bangladesh.

\section{Results and Discussion:}

The Government of Bangladesh (GOB) has emphasized the green development to reduce the negative impacts of climate change and promote a pollution free development in the country. The GOB has established the Bangladesh Climate Change Resilience Fund (BCCRF) in May, 2010 under signing a Memorandum of Understanding (MoU) with the World Bank and other development partners. Moreover, the GOB has established another fund namely 'Bangladesh Climate Change Trust Fund (BCCTF)' based on the allocation from national budget and under the legal mandate by the Parliament in 2010 (Hossain, 2019). Figure 2 highlights the GOB allocation to the Bangladesh Climate Change Trust Fund for the different fiscal year.

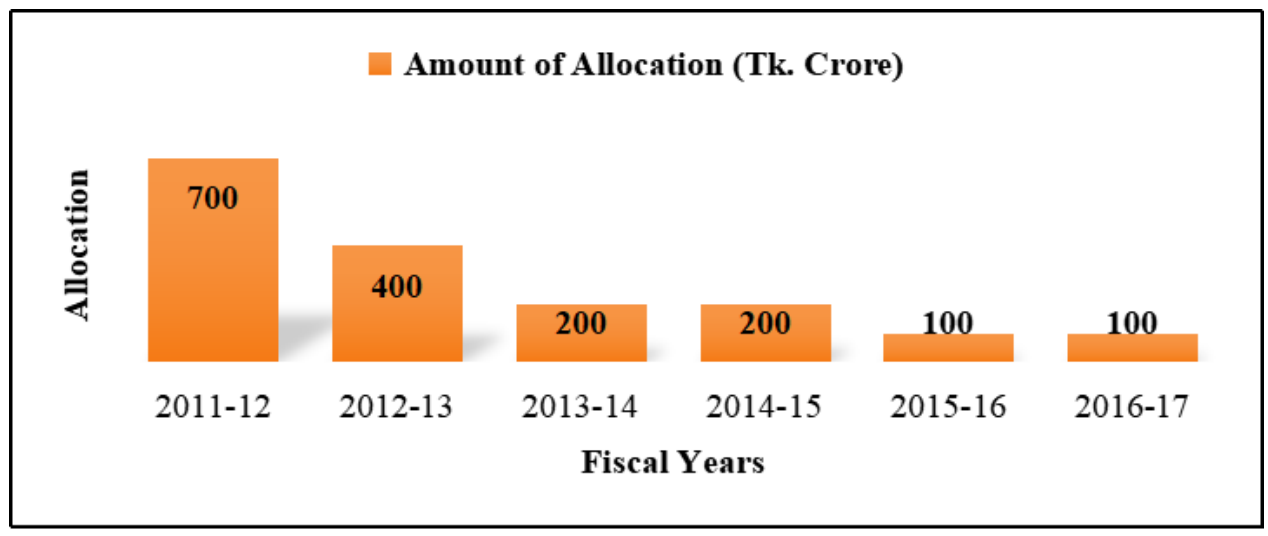

Figure 2: Government allocation to the Bangladesh Climate Change Trust Fund Source: BCCTF 2017

As visualized in Figure 2, the allocation to the Bangladesh Climate Change Fund (BCCTF) is the highest at the early stage of the fund development in 2011-12 fiscal year that gradually 
decreased. Because of separate policy undertaken by various ministries and other regulatory agencies with separate budget allocation following government initiatives, government allocation to the BCCTF need to be reduced.

Table 1 addresses the supportive initiatives of different government institutions in Bangladesh for green development. Bangladesh Bank (BB) is the controlling and regulating government authority for the commercial and specialized banks. The SREDA is working for promoting sustainable energy uses in the country. The Planning Commission is playing pioneer role for adopting and formulating policies for green development. Moreover, Finance Division and Economic Relations Division (ERD) are the authorizing bodies for supporting in fiscal policies, incentives and securing green finance for socioeconomic development in the country.

Table 1: Role of government institutions for green development in Bangladesh

\begin{tabular}{|l|l|}
\hline Institutions & \multicolumn{1}{c|}{ Initiatives } \\
\hline Bangladesh Bank & $\begin{array}{l}\text { Policy formulation and governance, introduction of green finance, } \\
\text { supporting employee training, consumer awareness, and green events }\end{array}$ \\
\hline $\begin{array}{l}\text { Sustainable and Renewable } \\
\text { Authorgy Development }\end{array}$ & $\begin{array}{l}\text { maintain coordination among the various organizations working on } \\
\text { green technologies, capacity building in terms of manpower, logistics, } \\
\text { and funds }\end{array}$ \\
\hline Planning Commission & $\begin{array}{l}\text { Inter-sectoral coordination among the related ministries, allocation of } \\
\text { resources towards implementation. }\end{array}$ \\
\hline Finance Division & $\begin{array}{l}\text { Preparing, analyzing, and implementing fiscal policies, budgets- } \\
\text { functions, allocate fiscal incentives. }\end{array}$ \\
\hline $\begin{array}{l}\text { Economic Relations } \\
\text { Division (ERD) }\end{array}$ & $\begin{array}{l}\text { External support for the socioeconomic development, securing green } \\
\text { finance from international sources. }\end{array}$ \\
\hline
\end{tabular}

Sources: Shakil et al. 2014

Bangladesh Bank, the central bank of the country has instructed the banks and financial institutions of the country for green banking and green credit through policy guidelines. The BB has formed 'Climate Risk Fund' to promote the green initiatives for the banks and financial institutions. The banks and financial institutions allocate at least $10 \%$ of their corporate social responsibility (CSR) budget to the climate fund. In 2016, the banks and financial institutions allocated a total amount of Tk.376, 078.12 million in 'Climate Risk Fund' and disbursed Tk. 503.2 billion as green finance (Bangladesh Bank 2016). The BB also encourages the banks and financial institutions for financing the green projects to ensure sustainable development in the country. Moreover, Bangladesh Bank has fixed 5\% mandatory credit quota for green finance out of the total loan disbursement of banks and financial institutions in 2016 (Hossain 2019).

The BB has formulated several policy guidelines for promoting green banking in the country. Firstly, BB has taken initiatives to formulate the necessary policies for in-house environmental performances and promote green banking by 2011. Secondly, BB motivated the banks and financial institutions to disclose their environmental activities and performances in websites and annual reports by the year of 2012. Thirdly, BB has required for the banks to publish sustainable annual report with maintain the international standard by the year of 2013. Moreover, the commercial banks are practicing several green initiatives through the instructions of BB such as 
green governance, paperless banking, install of solar energy in branches, promote green credit, green financing, and report on green banking activities (Ullah 2014).

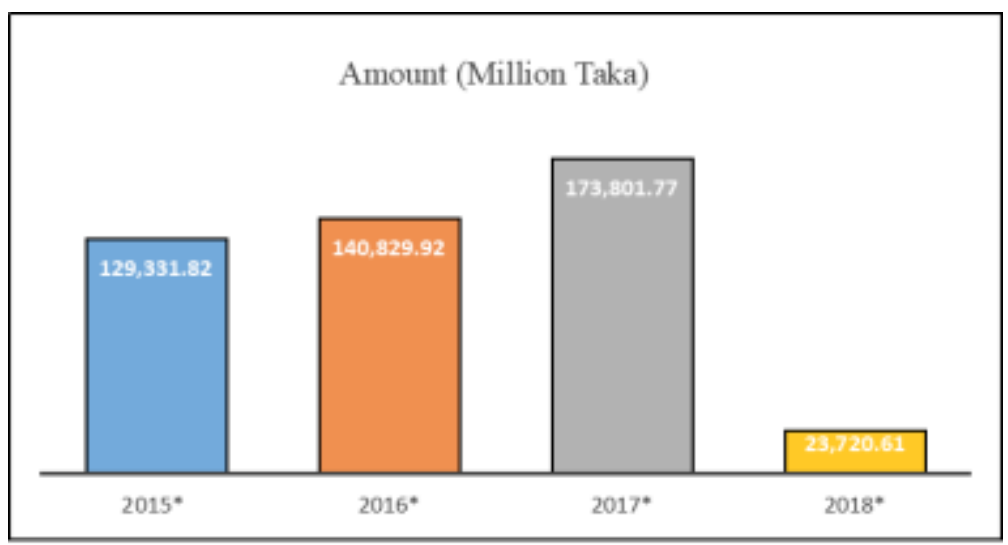

*Calculated from quarterly report of Bangladesh Bank during October-December in each year

Figure 3: Amount of green finance in Bangladesh

Source: Rana and Siddique 2019

Figure 3 illustrates an increasing trend for the amount of green finance in Bangladesh. The amount for the year 2018 is seems to be the lowest as it has been partially calculated from the observed data.

Bangladesh is one of the lowest performed countries in the world for environmental performance. According to the latest report of environmental performance index (EPI) 2020 by the Yale and Columbia universities in the United States, the country has ranked 162nd out of 180 countries that evaluates the condition of environmental health and vitality of their ecosystems. There are several initiatives like environmental taxes and ecological compensation mechanisms have been taken by the GOB for green development in the country. The GOB has contributed $7 \%$ of public expenditure for green growth activities in the country (Macgregor et al. 2016). The GOB has also proposed 1\% 'green tax' as 'Environmental Protection Surcharge' during the budget of 2014-2015 fiscal year for the factories who produce pollution in dangerous levels. This green tax influences the garment factories to set up waste treatment facilities and the brick factories for environment friendly production (Keane 2014).

Table 2: Environmental taxes in Bangladesh

\begin{tabular}{|c|l|}
\hline Taxation System & \multicolumn{1}{c|}{ Initiatives } \\
\hline Fossil fuel use & $\begin{array}{l}\text { The tax rate for selling price on fossil fuel- petrol }(12.9 \%), \text { diesel } \\
(10.2 \%), \text { kerosene }(10.2 \%), \text { and fuel oil }(15.7 \%)\end{array}$ \\
\hline Industrial air pollution & $\begin{array}{l}\text { Take initiatives to reduce air pollution focus on the transport sector and } \\
\text { the brick manufacturing }\end{array}$ \\
\hline Industrial water pollution & $\begin{array}{l}\text { The GOB has restricted the production and use of polyethylene } \\
\text { shopping bags and make mandatory to set up Effluent Treatment Plants } \\
\text { (ETPs) for industries to prevent waste discharge to water bodies }\end{array}$ \\
\hline
\end{tabular}

Sources: Ahmed 2018

Government also taking initiatives to facilitate the possibility of green bond facilities in capital market of the country. The World Bank and the BB have conducted a study on green bond 
development in Bangladesh during 2019. The study identified seven government bodies as policy and regulatory actors for green bond development in the country. The actors are the Ministry of Finance, BB, SREDA, the Bangladesh Securities and Exchange Commission (BSEC), the Insurance Development and Regulatory Authority (IDRA), the National Board of Revenue and the Dhaka and Chittagong Stock Exchanges. The proposed issuers of green bond are 59 scheduled banks, 34 non-banking financial institutions, and Finance Division (Ministry of Finance). The investors of green bond are pension funds, insurance companies, scheduled banks, international investors, large corporates, asset managers, and non-banking financial institutions (WB \& BB 2019).

The practices of green insurance are limited in Bangladesh than other South Asian countries. The GOB has prioritized to promote agricultural insurance as green insurance initiatives. Agricultureal insurance can be used as mitigation strategy to transfer climate risk away from the farmers. There are some insurance products on livestock, flood, and crops have offered in the country to mitigate climate change related negative impacts. Again, two weather index-based insurance initiatives have launched recently in Bangladesh. One initiative is led by governmentowned insurance company named Sadharan Bima Corporation and another initiative is led by private insurance company named Green Delta Insurance Company. Moreover, the World Bank has identified four potential types of agricultural insurances in Bangladesh through consultation with the GOB. The potential agricultural insurance are dairy cattle insurance, aquaculture insurance, crop insurance, and insurance for climate vulnerable people (World Bank Group 2018).

Readymade garments (RMG) and leather industries are two main export earning sectors in Bangladesh. The RMG sector contributes about 6\% to the Gross Domestic Product (GDP) of Bangladesh and around 4.4 million workers are engaged in this industry (Reza et al., 2017). On the other hand, lather industry is the second largest export earning sector of Bangladesh after RMG. Bangladesh has exported USD 1.13 billion of leather and leather goods in 2015-2016 fiscal year (Paul et al. 2013). Environmental degradation is a big problem for RMG and leather industries for disposal of solid and liquid waste in the nearby water bodies.

The GOB has emphasized on green production practices in RMG and leather industries to promote green trade in the country. The BB has set two hundred million dollars green fund namely 'Green Transformation Fund' to provide low-cost loans for green productions in RMG and leather industries along with others other export oriented industries. The low-cost loans will be distributed to support the green practices in the industries like waste management, water conservation, energy efficiency, renewable energy, resources efficiency, and recycling activities (Reza et al. 2017).

The GOB has played an important role through polices formulation and implementation of strategies for ensuring urban green space in the country (Swapan and Khan 2018). The GOB give special consideration to make Dhaka, capital of the country as inclusive livable city through emphasize on urban green spaces and green infrastructure (Byomkesh et al. 2012 ). The GOB give prioritize on policy attention of two ways for urban green spaces namely eco-aesthetic beautification (Matthews et al. 2015) and urban informal settlements for migrants (Gopal and Nagendra 2014). The RAJUK, capital development authority of Bangladesh has prepared 
Dhaka's overall development master plan for the year 2035 including green spaces, beautification opportunities, and green infrastructure (Hasan 2017).

The GOB has taken various innovations and policy support to prevent environmental pollution and mitigate climate change negative impacts. The Bangladesh Climate Change Strategy and Action Plan (BCCSAP) have developed in 2009 to ensure low-carbon development in the country. The GOB has flourished the Ministry of Environment and Forest (MoEF) as the Ministry of Environment, Forest and Climate Change (MoEFCC) to give emphasize on the climate change impacts for green development.

Moreover, the GOB has adopted a number of policies to promote green innovation in the country as well as ensure environmental well-beings (Rahman 2019). The mentionable policies are the Forest Policy (1994), the Energy Policy (1995), the Water Policy (1998), the National Conservation Strategy (1995), the National Environment Management Action Plan (1995), the Environment Conservation Rules (1997), and the Environment Court Act (2010). Furthermore, the GOB has adopted the Renewable Energy Policy of Bangladesh (2008) to promote renewable energy as green innovation in the country. A government institution namely Sustainable and Renewable Energy Development Authority (SREDA) has been established to create awareness and capacity building for renewable energy in the country. The main activities of SREDA aremaintain coordination among the various organizations for working on green technologies, demonstration of new technologies and market opportunities, provide subsidies in renewable energy projects and capacity building in terms of manpower, logistics, and funds (Shakil et al. 2014).

The GOB has prioritized green government procurement in the two policies namely Public Procurement Act 2006 and Public Procurement Rules 2008. Both the policies included several initiatives to ensure green government procurement such as green innovation, efficient use of spaces, consider environment friendly process, and incorporate energy saving procedures. Moreover, Central Procurement Technical Unit (CPTU) also consider some green practices in procurement like as health and safety issues, follows labor laws related to employment, minimum waste generation and exclude child labor (Ahammed 2015).

\section{Conclusion:}

Green development is a comprehensive approach to maintain balanced development in the country and ensure social, economic, and environmental well-beings for the people. It can be able to provide the impacts of climate change as national priority in Bangladesh. Green innovation can ensure the proper utilization of resources to increase the productivity in the country. The pollution especially air and water are high in the urban areas. Green development helps the country to control the pollution by imposing environmental taxes and compensation mechanisms. Moreover, green development ensures green growth in the country with employment opportunities, reduce environmental pollution, sustainable use of resources, proper management of waste, and generation of renewable energy.

Green banking and green credit facilities will ensure environment friendly business opportunities. The environmental taxes and ecological compensation mechanisms are limited in 
Bangladesh than other developing countries. The country need to increase the scopes of environmental taxes and mechanisms to reduce environmental pollution and sustainable production. The green bond and securities are helpful for creating environment friendly capital formulation in any country. The GOB should formulate and implement proper policy guidelines to create strong green capital market. Green insurance is suitable for Bangladesh to reduce the climate change risk in agriculture and other natural resources based production system. The GOB has promoted green insurance in the country especially in the coastal areas for reducing production risks.

The GOB required taking proper policy initiatives for the RMG and leather industries to ensure pollution free production system which ensures green trade initiatives as well as increases export earnings. The GOB should be implemented green space initiatives in all urban areas for sustainable and liveable urban development. The green government procurement is still less concerned matters in Bangladesh. As largest consumption authority, the GOB should practice green procurement in all stages of government procedures. Moreover, the GOB needs to encourage the green innovations to promote green development in the country. Finally, the GOB should make effective collaboration with all related stakeholders to ensure the green development.

\section{References:}

Acemoglu, D.; Akcigit, U.; Hanley, D.; Kerr, W. Transition to clean technology. J. Polit. Econ. 2016, 124 (1), 52-104.

Agyepong, A. O.; Nhamo, G. Green procurement in South Africa: perspectives on legislative provisions in metropolitan municipalities. Envir., Dev. and Sus. 2017, 19, 2457-2474.

Ahammed, K. F. Governance in Sustainable Public Procurement: Role of Supreme Audit Institution, Bangladesh. Unpublished Masters' Thesis of Institute of Governance Studies, BRAC University, Dhaka, Bangladesh, 2015.

Ahmed, S. Environmental Fiscal Reforms in Bangladesh. Working Paper, Economic Dialogue on Green Growth, Adam Smith International, UK aid, 2018.

Aizawa, M.; Yang, C. Green Credit, Green Stimulus, Green Revolution? China's Mobilization of Banks for Environmental Cleanup. The J. of Envir \& Dev. 2010, 19(2), 119-144.

Anand, I. M.; Gaur, S. S. Consequences of consumers' emotional responses to government's green initiatives: Insights from a scenario-based experimental study. Manage of Envir Qua: An Int. J. 2019, 30(1), 243-259. https://doi.org/10.1108/MEQ-02-2018-0045

Bangladesh Bank. Annual Report. Bangladesh Bank, Dhaka, 2016.

BCCTF. Bangladesh Climate Change Trust Fund, Government of Bangladesh. 2017. http://www.bcct.gov.bd.

Berrone, P.; Fosfuri, A.; Gelabert, L.; Gomez-Mejia, L. R. Necessity as the mother of 'green' inventions: Institutional pressures and environmental innovations. Stra. Manage. J. 2013, 34 (8), 891-909. 
Bihari, S. Green banking-towards socially responsible banking in India. Int. J. of Bus. Ins. \& Trans. 2011, 4(1), 82-87.

Byomkesh, T.; Nakagoshi, N.; Dewan, A.M. Urbanization and Green Space Dynamics in Greater Dhaka, Bangladesh. Lands. and Ecol. Eng. 2012, 8 (1), 45-58. doi:10.1007/s11355-0100147-7.

Chen, T.B.; Chai, L.T. Attitude towards the environment and green products: consumers perspective. Manage. and Sci. Eng. 2010, 4(2), 27-39.

Chen, Z.; Nie, P. Effects of carbon tax on social welfare: a case study of China. Appl. Ener. 2016, 183, 1607-1615.

CSRC. Notice on IPO application documents of manufacture companies in heavily polluting industries (CSRC Publication Number: 6). China Securities Regulatory Commission, 2008. http://www.sepb.gov.cn/wsbs/ssgshbsc/iposhenbao.htm

Droste, N.; Ring, I.; Schröter-Schlaack, C; Lenk, T. Integrating Ecological Indicators into Federal-State Fiscal Relations: A policy design study for Germany. Env. Pol. Gov. 2017, 27, 484-499.

Dufays, L. Responsible banking, the 10 principles. IEB Int. J. of Fin. 2012, 5, 238-269.

Falcone, P.M.; Sica, E. Assessing the opportunities and challenges of green finance in Italy: An analysis of the biomass production sector. Sustain. 2019, 11(517), 1-14.

Franks, M.; Edenhofer, O.; Lessmann, K. Why finance ministers favour carbon taxes, even if they do not take climate change into account. Green Growth Knowledge Platform $(G G K P)$, Proceeding of the Third Annual Conference, Fiscal Policies and the Green Transition: Generating Knowledge - Creating Impact, Venice, Italy, 2015.

Furrer, B.; Hamprecht, J.; Hoffmann, V. H. Much ado about nothing? How banks respond to climate change. Bus. \& Soc. 2012, 51(1), 62-88.

Gaur, A.S.; Kumar, M. A systematic approach to conducting review studies: an assessment of content analysis in 25 years of IB research. J. of Wor. Bus. 2018, 53(2), 280-289.

Gerlach, H.; Zheng, X. Preferences for green electricity, investment and regulatory incentives. En. Eco. 2018, 69, 430-441.

Gopal, D.; Nagendra, H. Vegetation in Bangalore's Slums: Boosting Livelihoods, Well-Being and Social Capital. Sustain. 2014, 6 (5), 2459-243. doi:10.3390/su6052459

Hafezalkotob, A.; Alavi, A.; Makui, A. Government financial intervention in green and regular supply chains: multi-level game theory approach. Int. J. Manage. Sci. Eng. Manage. 2016, 11 (3), 167-177.

Hasan, M. Gazipur Development Authority in the Offing. New Age, May 14, 2017. http://www.newagebd.net/article/15521/gazipur-dev-authority-in-the-offing

Hossain, M. Green Finance in Bangladesh: Barriers and Solutions. In: Handbook of Green Finance, Sustainable Development, J. D. Sachs et al. Eds.; Springer, ADB Institute, 2019; pp. 513-537.

Hu, A.; Yan, Y.; Tang, X. Xi Jinping's New Development Philosophy. Springer Nature Singapore Pvt. 2018. 
Huang, Z.; Liaob, G.; Li, Z. Loaning scale and government subsidy for promoting green innovation. Tech. For. \& Soc. Chan. 2019, 144, 148-156.

Keane, J. Bangladesh Introducing “Green Tax” Against Factories. Industry tap into news, June 17, 2014. https://www.industrytap.com/bangladesh-green-tax-against-factories/20741

Kim, J.; Park, K. Financial development and deployment of renewable energy technologies. En. Eco. 2016, 59, 238-250.

Lee A, Jordan H, Horsley J. Value of urban green spaces in promoting healthy living and wellbeing: prospects for planning. Risk Manag Health Policy. 2015, 8, 131-137. https://doi.org/10.2147/RMHP.S61654

Lennon, M.; Scott, M.; Collier, M.; Foley, K. The emergence of green infrastructure as promoting the centralisation of a landscape perspective in spatial planning - the case of Ireland. Lands. Res. 2017, 42, 146-163.

Lewis, J. I. Green Innovation in China: China's Wind Power Industry and the Global Transition to a Low-Carbon Economy. Columbia University Press, Washinsgton D.C., USA, 2012.

Macgregor, J.; Firoz, R.; Uddin, N.; Islam, S.; Sattar, M. A. Green Growth Diagnostic Bangladesh. Working Paper, Economic Dialogue on Green Growth, Adam Smith International, UK aid., 2016.

Matthews, T.; Lo, A. Y.; Byrne, J. A. Reconceptualizing Green Infrastructure for Climate Change Adaptation: Barriers to Adoption and Drivers for Uptake by Spatial Planners. Lands. and Urb. Plan. 2015, 138, 155-163. doi:10.1016/j.landurbplan.2015.02.010

Mell, I.C. Green infrastructure: reflections on past, present and future praxis. Lands. Res. 2017, $42,135-145$

Mohanty, M. New renewable energy sources, green energy development and climate change. Manage of Envir Qua: An Int. J. 2012, 23(3), $264-274$

Nesshöver C; Livoreil B; Schindler S; Vandewalle M. Challenges and solutions for networking knowledge holders and better informing decision-making on biodiversity and ecosystem services. Bio. and Conserv. 2016, 25, 1207-1214.

OECD. Scaling-up Finance Mechanisms for Biodiversity. OECD: Paris, 2013.

Paramati, S.R.; Ummalla, L.; Apergis, N. The effect of foreign direct investment and stock market growth on clean energy use across a panel of emerging market economies. En. Eco. 2016, 56, 29-41

Paul, H. L.; Antunes, A. P. M.; Covington, A. D.; Evans, P.; Phillips, P. S. Bangladeshi Leather Industry: An Overview of Recent Sustainable Developments. Soc. of Leat. Tech. and Chem. 2013, 97(1), 25-32

Pigato, M.; Heine, D.; Black, C. A.; Cali, M.; Forni, L.; Catalano, M.; Pezzolla, E.; Schuler, P.; Mele, G.; Antonio, M.; Oliveira, L.E.R. Fiscal policies for development and climate action: Policy summary for finance ministers. World Bank, Washington DC, USA, 2018.

Rahman, B. Green Governance: Where Bangladesh Stands? The Daily Sun, April 09, 2019. https://www.daily-sun.com/post/383940/2019/04/09/Green-Governance:-WhereBangladesh-Stands 
Rana, M.; Siddique, M.A.B. Green Banking in Bangladesh: A Descriptive Analysis. IOSR J. of Bus. and Manage. 2019, 21(7), 57-67.

Reza, A. K.; Islam, M. S.; Shimu, A. A. Green Industry in Bangladesh: An Overview. Envir. Manage and Sus. Dev. 2017, 6(2), 124-143.

Schiederig, T.; Tietze, F.; Herstatt, C. Green innovation in technology and innovation management - an exploratory literature review. R\&D Manage. 2012, 42 (2), 180-192.

Shakil, M. H.; Azam, M. K. G.; Raju, M. S. H. An evaluation of green banking practices in Bangladesh. Eur. J. Bus. Manage. 2014, 6(31), 8-16.

Srivastava, D. K.; Kumar, K. K. Environment and fiscal reforms in India. New Delhi: SAGE, 2014.

Swapan, M. S. H.; Khan, S. From Authoritarian Transplantation to Prescriptive Imposition of Good Governance: Tracing the Diffusion of Western Planning Concepts in Bangladesh. Int. Plann. Stu. 2018, 23(4), 340-354. doi:10.1080/13563475.2018.1489786.

Toyin, O. O.; Toyin, O. A. Carbon Fiscal Instruments and Green Finance: An Aid to the Success of SDGs in Nigeria? J. of Inn in Bus. and Eco. 2019, 3(2), 49-62.

Tzoulas, K.; Korpela, K.; Venn, S.; Yli-Pelkonen, V.; Kaźmierczak, A.; Niemela, J.; James, P. Promoting ecosystem and human health in urban areas using green infrastructure: a literature review. Lands. Urb. Plann. 2007, 81, 167-178.

Ullah, M.S. Green Banking in Bangladesh: Progress, Problems and Prospects. Prajnan. 2014, 43(1), 89-103.

Verma, R.; Gayithri, K. Environmental Fiscal Instruments: A Few International Experiences. Margin-The J. of App. Eco. Res. 2018, 12(3), 333-368.

Voumik, L. C; Shah, M. G. H. A green Economy in the Context of Sustainable Development and Poverty Eradication: What are the Implications for Bangladesh? J. of Eco. and Sus. Dev. 2014, 5 (3), 119-131.

Wang, C.; Nie, P.; Peng, D.; Li, Z. Green insurance subsidy for promoting clean production innovation. J. of Cle. Pro. 2017, 148, 111-117.

WB \& BB. Green Bonds Development in Bangladesh - A Market Landscape. World Bank Group and Bangladesh Bank, Dhaka, Bangladesh, 2019.

World Bank Group. Bangladesh: Policy Options for Crop and Livestock and Aquaculture Insurance. World Bank, Washington, DC., USA, 2018. https://openknowledge.worldbank.org/handle/10986/31039 License: CC BY 3.0 IGO.”

Yoshino, N.; Taghizadeh-Hesary, F. Alternatives to private finance: role of fiscal policy reforms and energy taxation in development of renewable energy projects. In: Financing for lowcarbon energy transition: unlocking the potential of private capital, Anbumozhi, V., Kalirajan, K., Kimura, F. Eds.; Springer, Singapore, 2018; pp. 335-357. 